\title{
Trinitarian spirituality: Relational and missional
}

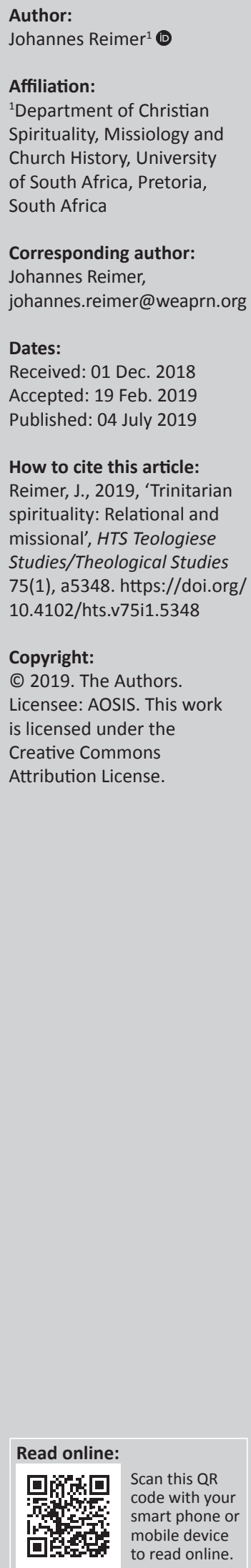

In recent years, Orthodox views on trinitarian theology have enriched the Evangelical discourse on mission and spirituality. Very few sources of Orthodox thought have influenced this discourse more than the hesychastic beliefs and praxis of the medieval Russian spiritual leader Sergii of Radonezh, as expressed by his disciple, the famous icon painter Andrey Rublev. This article discusses the theology of Rublev, follows its spirituality and explores a correlation between the inner-trinitarian spirituality and God's mission, establishing what is called a trinitarian cycle of the missio Dei.

Keywords: Mission of God; Russian Orthodox Theology; Hesychasm; Trinity; Trinitarian theology; Correlation between mission and spirituality.

\section{Missio Dei as missio trinitatis: An introduction}

Christian spirituality and Christian mission refer to God as Trinity: the Father (Mt 6:9-13), Son (Jn 1:1.14) and Holy Spirit (Jn 14:16.26), the Lord of mission (2 Cor 3:17). To explore God in the New Testament means, therefore, to explore God in his Trinity (Wright 1992:201). Mission is central to the theology of the New Testament (Marshall 2004:36; Wright 2006:50), and as such it is trinitarian in nature. The German theologian Hahn speaks about the 'implicit trinitarian structure of the new-testamentarian witness' (2002:290). The mission of God in the world is a mission of a triune God as Jesus in his great commission in Matthew 28:19-20 suggests (for more detail, see Volf 1998:195). The missio Dei is in fact a missio trinitatis. Accordingly, missionary spirituality follows the same trinitarian pattern. But what does this mean for the theory and praxis of mission and spirituality?

The answer to this question will directly relate to how we see Trinity. Do we see the trinity relationally as St Augustin was suggesting? Augustin's concept of persona est relatio is still widely used in Christian traditions despite major problems (Reimer 2013:152-153; Volf 1998:204). I suggest seeing the three persons of the trinity as subjects (Volf 1998:204). A subject is defined according to its nature and in its relation to others. Moltmann proves in his writings that such a concept overcomes the potential reductions of the Augustinian concept (Moltmann 1991:11-21, 117-128). Each person of the trinity is seen in this model in her own nature as well as in relation to the other two.

It was the church father John Damaskin (675-749) ${ }^{1}$ who first suggested the concept (Gladis 1999:4ff.). He described the trinity as an eternal cycle, a perichoresis, in Greek for round dance. According to Damaskin, each person of the trinity is vitally existing in the other two without losing his own identity. Miroslav Volf calls such a construct reciprocal interiority (Volf 1998:209). We find this type of thinking predominantly in the Johannine writings in the New Testament. John sees the father in the son and the son in the father (Jn 17:21). Divine unity is an act of interiority, and as such it has enormous meaning for both mission and spirituality.

Nobody has ever expressed this truth better than the Russian orthodox iconograph Andrey Rublev (1360/1370-1430). His icon of the Holy Trinity painted in 1425 for the famous monastery of the Holy Trinity in Radonezh near Moscow is in all regards a highpoint of theological reflexion on the issue. ${ }^{2}$ The icon shows the divine persons around a table with a cup of offering, indicating a discussion on the matter. All three are painted equal, there is no hierarchy, no superiority, and the three are bound by a movement around the table of the Lord, the Eucharist.

1.For John of Damaskus, see BBKL: http:///www.bautz.de/bbkil/j/Johannes_v_dam.shtml.

2.The Icon is preserved in the Tretiakov Museum in Moscow.

Note: The collection entitled 'God as One', sub-edited by Erna Oliver (University of South Africa) and Willem Oliver (University of South Africa). 


\section{A world of theology in an icon ${ }^{3}$ Rublev: The man and his work}

Andrey Rublev ${ }^{4}$ (Andrei Rublev, Andrey Roublyov) is considered to be the greatest medieval Russian Orthodox painter of icons and frescoes. He was born in 1360 or 1370, and his place of birth is unknown. Little is known about his life. Orthodox historians believe that he was a monk of the monastery founded by the famous monastic father Sergii of Radonezh. ${ }^{5}$ Sergii died in 1392 . His successor became Nikon of Radonezh. It is believed that Nikon was the spiritual father of Andrey Rublev. ${ }^{6}$

Rublev's name was first mentioned in 1405 as one of three artists decorating the Cathedral of the Annunciation in the Kremlin of Moscow. The other two masters were Theophanes the Greek and Prochor of Gorodets. Both are well known in Russian religious history (see Ilyin 1976; Popova 1980). Rublev is mentioned as the last in the list, pointing to the fact of his relatively young age and, probably, monastic status. According to Russian Chronicles, Rublev had also painted icons and frescoes in the famous Assumption Cathedral of Vladimir (1408) and in the cathedral of the St Trinity in the Troitse-Sergieva Lavra in Radonezh (1425-1427) and others. Rublev did his last work in Moscow for the Andronikov monastery. He died in the Andronikov monastery on 29 January 1430. However, historians question this date.

Rublev's art has influenced generations of religious icon painters in Russia. At the Church Council, the famous Stoglav Sobor in 1551, Rublev's style of icon painting was announced as a model of Russian Orthodox secret painting.? Centuries later, the Russian Orthodox Church canonised Andrey Rublev in 1988, the year of the millennial celebrations of the church, underlining the importance of his work to the spirituality of Russian Orthodox believers. The church celebrates his memory on 04 July. ${ }^{8}$

\section{Rublev's art of icon painting and the St Sergius Spirituality of Radonezh}

Andrey Rublev's spiritual life was formed under the influence of the monastery of the Holy Trinity in Radonezh. Founded by St Sergii of Radonezh (1313/1314 or 1321/1322-1392), ${ }^{9}$ the place became a spiritual centre of Orthodox monastic spirituality for centuries (Reimer 1994:161). St Sergii escaped

3.This part of the article was first published in Reimer (2008:166-180).

4.Russian: Андре́й Рублёв.

5.For more information on Sergii, the foundation of the monastery and his spiritual legacy, see Reimer (1996:157-173).

6.There are a number of publications on Rublev, his life, art and theology. See, for instance, Demina (1972), Ilyin (1976), Polunin (1974), Popova (1980), Sergeyev (1981), Uspenski (1989), and Ulyanov (2005).

7.See full text of the council at http://nesusvet.narod.ru/ico/books/stoglav.htm.

8.The Soviet Government installed in 1959 a Rublev museum in the Andronikov Monastery of Moscow. The museum introduces visitors to the great art and work of the master and introduces the spirituality of the monks of the Serii of Radorezh the master and introduces the spirituality of the monks of the Sergii of Radonezh era. In 1966, Andrei Tarkovsky made a film on Rublev. For more information on Rublev and the biblio (1994:908-911).

9.See the discussion on the life dates of St Sergius in Reimer (1994:161f.). the turbulent life of continual political strife and rivalry among Russian feuds and built his monastery in the secludity of the Radonezh forest. Fascinated by the unity and peacefulness of God, presented by the concept of Trinity, he devoted the place to the Holy Trinity. Consequently, ideas of fraternity and brotherhood, calm and peace, love to God and the neighbour, and in all of this a spiritual perfection and self-improvement were expressed and lived by. Here in Radonezh the monastic brothers found peace from all the political and societal turmoil. St Sergii lived an ascetic and quiet life, adhering to the monastic school of hesychasm of Gregory Palamas (1296/1297-1359), ${ }^{10}$ but this did not separate him from his nation. Deeply involved in the destiny of his Russian people, he called for unity among the feudal rulers and condemned strife. His main political message was a message of liberation from the Mongol yoke. No other Russian Orthodox has ever been praised and followed as much as St Sergii. ${ }^{11}$ His vita was first written by one of his followers, the Moscovite Epiphanius the Wise, in 1417-1418, shortly after the death of St Sergii (Golubinski 1892:76; Reimer 1994:162).

The theology of St Sergii is deeply rooted in the trinity. Here he found his basic theological foundation for unity and power, the harmony of peaceful existence and the dynamic of a divine intervention. Epiphanius the Wise wrote that the monastery was founded so that 'contemplation of the Holy Trinity would conquer the hateful fear of this world's dissensions' (cit. Dunayev: Reimer 1994:164). St Sergii's theology is deeply missional, as the missiological analysis of his life shows (Reimer 1994:172ff.). He seeks the salvation of the individual, a theotic transformation in God's image (1994:172), driven by the idea of a possible theofication of humankind (1994:174). Salvation of the individual leads to the mission of service for the neighbour, the people, the nation. This requires full dedication, an offering of oneself for the sake of others (1994:176ff.). In other words, kenosis precedes theosis. The Mission of God into the world is a kenotic action (Reimer 1994:205) and aims towards a spiritual enlightenment of the land and its people (1994:206f.).

For St Sergii, the missional transformation started in the quiet of the personal devotion of the believer before God. And he saw the best place for such a meditative empowerment in the eucharist (Reimer 1994:209). In the Eucharistic community, the divine presence of the Holy Trinity was experienced. Here the faithful believer received the inner light, the hesychastic light of tabor, a prerequisite of theosis.

Rublev combined in his art the ascetism of the Russian ascetic monasticism as it was best expressed in the life and work of Sergii of Radonezh and the classic harmony of Byzantin iconography. His characters seem frozen in deep spiritual peace. The movement is assumed inwardly. There is 10.For more on Palamas, see Meyendorff (1964).

11.Russian Orthodox historians are full of admiration for his work. Gulubinski (1991:149), for example, calls him one of the three spiritual founding fathers of the Russian nation. 
a 'holy calmness' ruling his paintings. A more thorough analysis of his art as presented in the icon of the Holy Trinity will clearly show the dependency of his art on St Sergii.

\section{The icon of the Holy Trinity}

The most famous of all Rublev's paintings and the only fully authenticated is The icon of the Holy Trinity (Nikiforov 2001:619), illustrated by the Old Testament story of the three visitors to Abraham (Gn 18:1ff.). In Russian Orthodoxy, the scene is known as 'Hospitality of Abraham'. Rublev painted this icon possibly in 1425 (Dunayev) for the St Trinity Cathedral of the St Sergii's monastery in Radonez. ${ }^{12}$ His vita was by this time available to him. Rublev not only dedicated his icon to St Sergii but also attempted to gather the best of St Sergii's theology into one iconical image. The icon represents a summa theologia of St Sergii as it was perceived by Rublev and his contemporaries. To understand Rublev, we will have to understand St Sergii; also the icon opens a better view on what made St Sergii a father of Russian Orthodoxy and, for centuries, determined the destiny of a whole people. The meaning of this painting for Russian spirituality cannot be overestimated.

The icon exemplifies Rublev's genius to transcend the painting with spiritual ideas. The icon literally produces a lyrical aura of harmony and quietness and yet the same time seems to invite a rhythmic movement of an unstoppable power. Nikiforov wrote: 'In the rhythmic movements of the characters presented in the icon lays the fascination of the icon and its composition' (2001:619).

Rublev's icon is a perfect composition. Every detail has its meaning. To remove one of them means to harm the total meaning of the icon.

The subject of the icon is based, as mentioned above, on an Old Testament narrative of three men from God visiting Abraham and Sarah, announcing the birth of their own son Isaak (Gn 18,1-2). The biblical story is deliberately chosen. In the Orthodox tradition, the angels are believed to be the three persons of the Holy Trinity: God the Father, Jesus - the Son and the Holy Spirit.

Rublev was by far not the only one who used the Old Testament narrative for an iconographical image of the Trinity. The first iconographic paintings (see Figure 1) around this narrative are known from the 5th century onwards. But his icon is in many ways different from the Western as well as Eastern parallels of contemporary iconography. They all seem to portray the narrative. The icons are overloaded with details of the story. Rublev's masterpiece is different. The original Old Testament narrative is literally removed to a barely recognisable background. You will discover a little house over the left angel, a tree over the middle angel and a mount over the head of the right angel. The observer, knowing the narrative, will imagine the biblical scene of 12.The icon is preserved in the Tretiakov Gallery of Moscow.

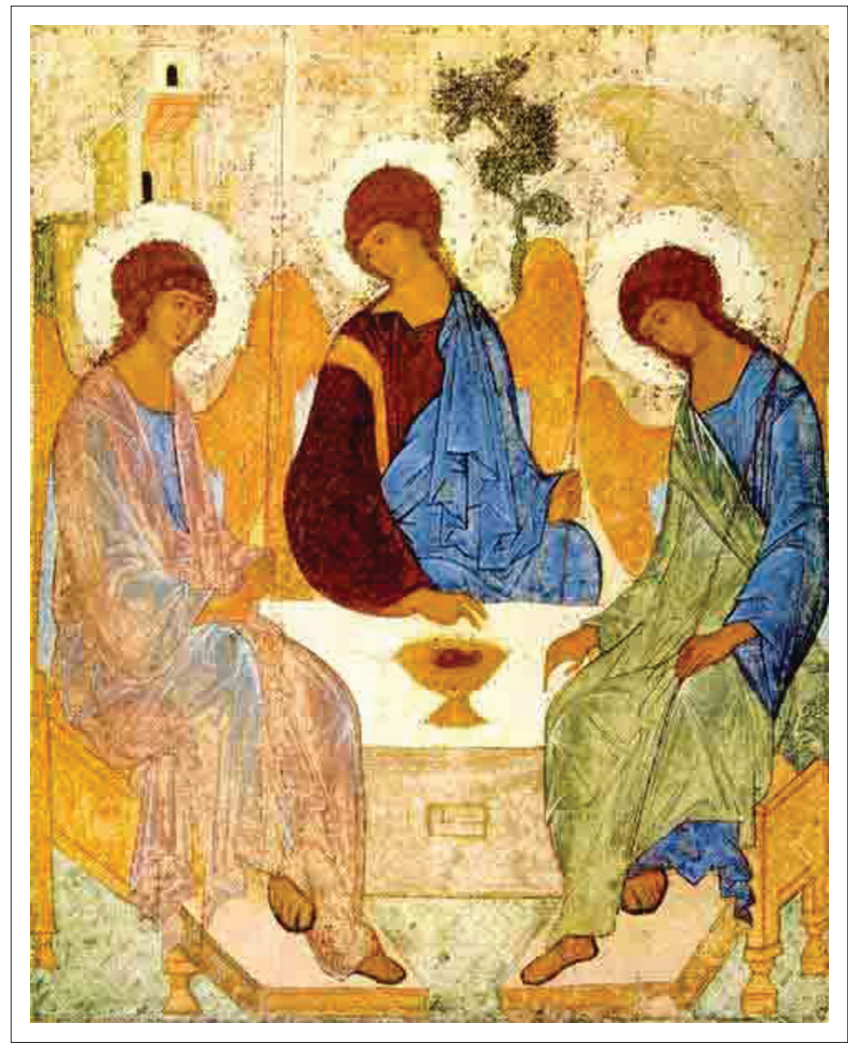

Source: Wikiart, n.d., Rublev: The icon of the Holy Trinity, viewed n.d., from https://www. google.com/url?sa=i\&rct=j\&q=\&esrc=s\&source=images\&cd=\&cad=rja\&uact=8\&ved=2ahUK google.com/url?sa=i\&rct=j\&q=\&esrc=s\&source=images $\& \mathrm{~cd}=\& \mathrm{cad}=\mathrm{rja} \& \mathrm{uact}=8 \&$ ved $=2$ ahU
Ewim4KyMm7TiAhXKLVAKHV4NAhYOjhx6BAgBEAM 4 url=https $\% 3 \mathrm{~A} \% 2 \mathrm{~F} \% 2 \mathrm{Fww}$. wikiart. org $\% 2$ Fde $\% 2$ Fandrei-rubljow $\% 2$ Fdreifaltigkeitsikone-1410\&psig=AOvVaw3gDdsunm5NuQ XqfuURZgg-\&ust $=1558788844354322$

FIGURE 1: Rublev: The icon of the Holy Trinity.

Abraham's house at the Mamre tree, with a view to the mounts of the Judean desert. But this background seems of no importance to the iconograph. The narrative as such is dissolved in a higher meaning of the story. Rublev seems to apply an allegorical reading of the narrative. Pavel Florensky is right when he states the icon:

... does not illustrate the story at Mamre. The story itself is rather rudimentary. The icon presents a surprizing vision of the Holy trinity itself - it is a new revelation, even if embodied into an earlier revelation of the Trinity, which, without doubt, seems of less importance in form. (Florensky in Raushenbach)

Rublev reads the character of the Trinity, and in this the iconograph is all New Testamental. Orthodox fathers saw the Abrahamitic narrative as a revelation of God's Trinity because of the voice from heaven confirming the Son in Mt 3:16-17. Dunayev clearly justifies the reading of the Old Testament from the perspective of the New Testament on the basis of this passage. God's three angels in Genesis 18 reflect the three persons involved in Matthew 3 (Dunayev).

Rublev paints his icon as a Russian, Eastern Orthodox iconographer. Compared to West-European, Roman Catholic iconography, which seeks outward expressions and tends to be more naturalistic, ${ }^{13}$ Russian masters expressed eternity by absolute exclusion of movement. All energy seems to be 13.For more to understand the differences, see Uspenski (1989), Lazarev (1983) and Lossky (1947). 
concentrated on an inward perspective. The iconographer moved from the outward to the inward. To depict the hidden beauty of the heart and soul of the matter was much more important than to grasp the natural attraction. Rublev's icon in this regard is typically Russian. All movements are frozen in an eternal moment. There is a deep quiet peace and calmness in the painting.

One more structural observation is important for our understanding of the icon. Iconography is a secret art. It follows strict standards. In Rublev's times, two traditions of painting the Trinity were accepted and ruling the day. Both of them were based on the teachings of the Church fathers (see Ratner). The first may be called a 'christological type'. Here the icon was arranged around the middle angel, which represented Jesus Christ. His figure was overwhelmingly bigger than the other two. His face was turned to the observer. He dominated the composition totally. The Trinity was perceived in Christ and in Christ only. The faithful observer came to the triune God because he came to Christ. This is the oldest iconographic tradition.

The younger one painted the three angels on equal terms. It is, therefore, called 'trinitarian type'. Their clothing and gestures indicated the relationship between them. All three faced the observer and the believer was confronted with three faces, marvelling them as a spectator.

Rublev completely changed the composition. He used elements of both types, it seems, but his arrangement takes the observer inside the icon. The figures do not face the observer at all. Rublev painted his icon in a reversed perspective. The middle angel approaches the table, not the observer. In an Orthodox Church arrangement, the priest approaching the table of Eucharistic offering faces the altar, turning his back to the people. Here the observer finds himself or herself behind the altar in the holy of holy. Rublev obviously seeks to allow his viewer an inner perspective on the Trinity. He wants us to see God in his very being rather than marvel the outward deeds and historic appearance. He wants a mystic experience more than anything else. The observer is invited to enter the window to Eternity, to step into the icon to discover God himself. The three angels image God in his Trinity. The faithful observer is supposed to read God in its form, colours and figures.

How does the artist achieve his goal? What composition does he create, and which colours does he use? The first surprising decision of the author is the cyclical arrangement of his figures. The angels are part of a cycle. In Eastern iconography, a cyclical positioning of iconic images in square formats was factually unknown before Rublev. Rublev was the first to combine the composition of a cycle with a square format of the painting. The cycle and especially cyclical movement were viewed in patristic theology as an expression of eternity, as seen in the writings of Dionysius Areopagites. ${ }^{14}$ The eternal peace expressed by the three angels composing a perfect cycle seems to indicate God's never-ending love. Dunayev states that ' $[t]$ he truth which the icon expresses best is the beauty of God's love' (Dunayev).

The analysis of the individual characters of the icon supports this view. God Father is presented by the angel to the left side. This is obvious through the house above his head, symbolising the house of creation. He is the creator of the universe. The other two angels bow to him. The angel in the centre represents Christ, which becomes obvious through the tree above him. The tree stands for the Cross and the redemptive work of God the Son. The mount above the third angel points to the Holy Spirit. Mountains symbolised spiritual uplifting in the Old Testament and similarly in the New Testament. ${ }^{15}$

The three angels sit around a table for offerings. It is not a dining table, which you would expect coming from the Old Testament story. The table is clearly identified as a secret table of offering with a cup in the middle. The head of the Lamb in the cup points to the New Testament image of the Lamb of God, who sacrificed himself for the sin of humankind (Phlp 2:5-11).

It is not too difficult to discover a eucharistic meal in the image of the icon. The three angels seem to converse over a secret meal and the meal is an offering of themselves. The form of the image seems to indicate this clearly. The two side angels seem to build with their bodies handles lifting up the cup which embraces the middle angel. The conversation at the table is concentrated on a matter which involves the three directly. The faithful observer is reminded that the divine salvation of humanity in Christ is the work of the whole Trinity. The centrality of Jesus is embodied in the totality of God.

The gestures in the image support such a reading. The hand movement of the left angel (the Father) points to the cup, calling the Son to take upon himself the work of salvation, and the head of the middle angel (the Son) gently bowed to the Father seems to indicate faithfulness and total obedience. 'Not my, your will be done' (Mt 26:39) is what the gesture says. And the third angel seems to witness the holy act of godly self-dedication. His total appearance reminds us of a comforter, the Paracletes, who will comfort the faithful whereever they are and whatever they do in the Name of the Almighty.

The iconograph has wonderfully arranged the light colours in a way that the angels seem to light from the inside. They are the sources of light for the rest of the icon. The observer has the impression that the light falls from the icon on him an amazing artistic effect.

Surprising is the fact that all three persons are painted equal. For the Orthodox theology of the Trinity, it is an amazing decision. The icon does not carry any hierarchical imagery. 15.See, for instance, Psalm 121, 1f. 
The three are one in totality. Divine unity is obviously at the centre of Rublev's theology. This is what he wants the faithful observer to see and believe.

The complete unity is expressed in amazing human categories. The image does not picture any movement or noticeable earthly energy and yet the forms suggest a deep relationship of love. There is no cold spirit of an abstract reality far removed from the human. The opposite is true. The three angels perfectly relate to one another, creating a cycle of perfect love. Vzdornov (1981:205ff.) sees in the image of the icon a striking balance between soul and spirit, the bodily and the immaterial. The persons appear to the observer as quiet and gentle, but at the same time with an amazing inward energy. There is a typical Russian anxiousness and sorrowfulness in their expressions, they invite to meditate, contemplate and foster intimate relationship with God. At the same time, there is a powerful missionary energy inviting to leave the place and enter the battlefield of life with the message of the Cross and Resurrection.

\section{Theology of The icon of the Holy Trinity}

What is the theology behind the icon? What did Rublev want to transmit to the visitors of the cathedral of the Holy Trinity in Radonez? What is his message? There are a number of possible conclusions.

Firstly, Rublev seems to express the UNITY, the divine ONENESS of the Trinity. Both the composition of his icon and the conversational relationship of the main images, the three angels, strongly support this thought, as we have seen previously. The oneness is a qualitative unity. It seems to describe the very nature of God in missionary terms. Uspenski states:

If the bowing of heads, expressed by the two angels towards the third unite the three, then the hands pointing to the cup on the white throne like table with an eucharistic cup filled with the head of an animal offering, point to the centre of the icon. (Uspenski in Raushenbach)

This centre is the Eucharist, God's salvific act in Christ, the ultimate target of the missio Dei. The unity of God is therefore qualified by the unity in God's mission. In fact, it seems to be the mission, which basically determines the nature of the Trinity.

Secondly, Rublev underlines the ETERNITY of the Trinity. He does this by freezing all motions in his painting. By doing so, he seems to stop the very time factor. Time is taken out of the icon. What is left lies behind time and space - Eternity! His icon speaks, but instead of words, stories; it uses meditation, emotions, as if the author wanted to say - you cannot describe God's divine nature, his everlasting love and his self-denial in mission in words. Love must be experienced. Verbal debates lead nowhere. God must enter the inner of our heart - intellectuality alone, reflection in time and space do not enter his nature. They may rather hinder access to the most secret, the most intimate - God himself in his Trinity. One is clearly reminded of God's prohibition to make any likeness of him (Ex 20.4). It is most fascinating to see an image of God expressing God's law prohibiting imaging! Rublev does not offer an idol; he leads to a deep contemplation of the unseen.

Thirdly, the unity of the Trinity is specified by some differentiations between the three images. Rublev does so by painting the dress of the angels in different manner. The different dresses seem to indicate different MISSIONS, responsibilities, offices of the three. They are one, their mission is one, centred on salvation, but their missionary tasks are different. As indicated by the symbols above their heads, they each play a different role, yet without being separated from each other. One does what promotes the other. Their acts seem to draw them near to their eternal oneness. Similarly, the positions of their bodies - the three all sit differently, but again the bodies seem to enter a perichoretical movement, a round dance, a rotation, which soon with speed gained will make it impossible to distinguish who is who in the picture. The observer following the direction in which the bodies point will soon rotate his head and will not take long and the meditation will produce a dancing effect. Rublev sees the differences in the hypostases of the Trinity. But he does so as John of Damaskus (675-749) once suggested - perichoretically. It will be impossible to separate one person of the Trinity from the other. They naturally belong together. There is just one being. The three are one. All polytheistic tendencies are removed. Rublev is, in his icon, absolutely monotheistic.

Fourthly, at the centre of the icon is CHRIST. He reveals to us humans God. It is his salvific act that seems to allow the observer to meditate on the nature of the Trinity. The quiet conversation, the presupposed dialogue between the three persons, seems to rotate around the table with the cup of offering. The frozen in time conversation indicates an eternal, never-ending dialogue. The WORD is not only spoken by God, God himself is this word. His nature is focused in this dialogue. Rublev wants his observer to see this. The attention of the observer is drawn to this table. The angels to the left and right seem to lift the table up with their bodies painted into the table. The composition indicates that the two offer the third. He is what they want to be seen. Rublev seems to indicate what the Prologue of the Gospel of John expresses clearly in unforgettable words:

In the beginning there was the Word and the Word was with God and the Word was God. All things came into being by Him; and apart from Him nothing came into being. IN Him was life and the life was the light of men ... And the Word became flesh and dwelt among us, and we beheld his glory. (Jn 1:1-2.14)

Fifthly, the colours of the icon are consciously chosen. Rublev uses a mixture of deep blue and dark red in a combination which allows him to create the impression of light shining out of the icon. The intentions of the iconograph as interpreted later were to create a place of divine meditation which would allow the observer to enter the divine light of God in order to 
experience an inner transformation. The idea behind comes from the hesychastic movement in the Greek monastic circles, around the Athoec monk and later archbishop Gregory Palamas, the founder of Hesychasm (Meyendorff 1964). ${ }^{16}$ Gregory and his followers believed that the experience was granted to the three disciples of Jesus, who went with him to the Mount Tabor, the mount of transfiguration, of being transformed by an amazing divine light, which they called the taboric light (for more detail, see Lossky 1997a).

Rublev and his great spiritual father St Sergii of Radonezh were hesychasts. The icon in their teaching became a window to God's divine taboric light. Rublev aimed to paint such a window. His task was not only to produce an image of the Holy Trinity; he wanted more. The icon in the hands of Rublev turns to a place of divine inspiration, a materialisation of God's presence. Meditating on the content transported by the icon allows the observer to enter a holy space where a personal transfiguration becomes a real chance. To be transformed in God's likeness, the theosis, is the highest goal of all hesychastic piety. 'God has become human in order that humans become godly'. And by individual transformation, nations will be transformed.

Sixthly, this is the point where the missional theology of St Sergii finds its commendable part. The icon of the Holy Trinity invites meditation and contempation in Eucharistic terms. But what it does with the faithful is that it enlightens him or her for the sake of the divine mission. Jesus at the table invites us to accept the same calling he received from the father. 'As the father has sent me, I am sending you', quotes John the Evangelist Jesus (Jn 20: 21). The liturgical experience of the Trinity becomes a divine calling to become instruments of salvation to the world. This has been the message of St Sergii (Reimer 1994:207f.) and this is the message of Rublev and his masterpiece.

\section{A source for spiritual inspiration for today}

Historians have described Rublev's icon as an iconographical image of the Russian Orthodox character. In its form and content, it generalises the best and the deepest sense of being an Orthodox believer. Here faith is embodied in an earthly image of a unified collective of people, deeply involved in conversation about the centre of what faith is all about - the Eucharist. The divine collectivity is expressed by the Russian Orthodox term sobornost, a togetherness of a Eucharistic community which was prominent in the works of the Russian Orthodox theologian A.S. Chomyakov. Professor Dunaev of the Moscow Orthodox Academy, the highest theological institution of the ROC, says: 'Sobornost is in essence a quality of the Holy Trinity and as such represents an ideal for the spiritual development of humanity' (Dunayev).

Rublev's icon was and is a foundational source of Russian iconography, especially where it relates to the Trinity. Orthdoxy of the 14th century, see Cappon and Clucas (1985).
Trinitarian theology of the Russian Orthodox church finds here its master, as Raushenbach puts it (Rauschenbach n.d.). The icon of the 'Holy Trinity' is much more than a theological expression, or a liturgical point of departure in Orthodox worship. According to St Sergii, the Trinity symbolises unity in all Christian life, regardless of whether it is spiritual, social or political. No wonder Rublev's icon became one of the main images and symbols in Chomyakov's idea of sobornost. In this icon, the 'Holy Russia' finds its best expression. Here the Russian Orthodox nation rests in its eternal calling, preserving national unity by keeping the only true Orthodox faith. In the words of Ulyanov (2005): 'Our national idea is in the icon of Andrey Rublev'.

Rublev's masterpiece has been marvelled and copied many times. It has inspired poets and theologians, philosophers and musicians. The deep spirituality of the icon seems to offer a foundation for all those who seek God's presence. The great Orthodox theologian Pavel Florensky once said: 'There is the Trinity of Rublev and this means there is God' (ct. Dunayev).

In times of post-Christianity in Europe, Rublev's message is as actual as never before - not only for the Russians and their Orthodox Church. It is a universal message, inviting us to seek and contemplate on unity in mission of transformation, unity which derives its strength from the kenotic heart of God, ready to sacrifice his only begotten Son in order to save and reconcile humanity (2 Cor 5, 17-21; Jn 3, 16). Apostle Paul once summarised this in his famous Christ song, by saying:

Have this attitude in yourselves which was also in Christ Jesus; who although he existed in the form of God, did not regard equality with God a thing to be grasped, but emptied himself, taking a form of a bound-servant. And being made in the likeness of men: And being found in Appearance as a man. He humbled Himself by being obedient to the point of death, even death on a cross. Therefore, also God highly exalted Him, and bestowed on Him the name which is above every name, that at the name of Jesus every knee should bow, of those who are in heaven and on earth and under the earth, and that every tongue should confess that Jesus Christ is Lord, to the glory of God the Father. (Phil 2:10-11)

\section{Missio trinitatis}

Rublev's icon of the Holy Trinity expresses a spirituality rooted in eternal unity and endless love aiming to reconcile the world with God - a world created by God, a world he loves and seeks to change. The triune God is a missionary God. How do the authors of the New Testament capture this very thought? Let us examine some of the New Testament passages in this regard.

\section{Missio Patri - Laying foundations}

God is engaged with the world? Why? What motivates his missionary heart? What is he aiming for? The simplest answer given in the New Testament is as follows: God loves the world he made and his love to the world forces his 
divine engagement. Love to the world is the strongest motive behind the missio Dei (Freitag 1950:1ff.). And love is God's nature. He is love (1 Jn 4:8). To leave the world corrupted by Satan to his destructive power would run totally against the very nature of God. The evangelist John quotes Jesus, saying: 'For God so loved the world that he gave his one and only Son, that whoever believes in him shall not perish but have eternal life' (Jn 3:16).

God the creator of the world loves his creation so much that he is offering himself to save the world from destruction. Love as a basic motivation for God's saving action is already mentioned in the Old Testament. In Isaiah 63 we read:

I will tell of the kindnesses of the Lord, the deeds for which he is to be praised, according to all the Lord has done for us - yes, the many good things he has done for Israel, according to his compassion and many kindnesses. He said, 'Surely they are my people, children who will be true to me'; and so he became their Savior. In all their distress he too was distressed, and the angel of his presence saved them. In his love and mercy he redeemed them; he lifted them up and carried them all the days of old. (vv. 7-9)

God saves because he loves and has mercy! This is the main reason for his acts in the world. His love is based on a decision he made long before the world was created. Apostle Paul states in Ephesians 1:

Praise be to the God and Father of our Lord Jesus Christ, who has blessed us in the heavenly realms with every spiritual blessing in Christ, or he chose us in him before the creation of the world to be holy and blameless in his sight. In love he predestined us for adoption to sonship through Jesus Christ, in accordance with his pleasure and will - to the praise of his glorious grace, which he has freely given us in the One he loves. (Eph 1:3-6)

God has decided to love the world long before he made it. He is a loving father! The Mission of God is anchored in his love to the world. Whoever joins God's mission will enter a living stream of love flowing into the world. Loving God always results in love to the neighbour. The two are interrelated (Mk 12:28-34 par). ${ }^{17}$ Change in the world presupposes love for the world. Only those who love are ready to offer their own life for the loved ones. God loves the world, and this is the reason why he offers himself in the Son for the salvation of the world.

Love is the foundational ground of mission. Bosch (1991:208-209) observes that the first Christians were moved by love and John 3:16 can be seen as the main foundational text of their mission. Loving the neighbour was for Jesus and his disciples daily praxis of life. The German theologian Wilkens (2002:258), who studied Jesus preaching in the gospels in great detail, writes: 'All this sayings seem to interpret the law of charity in Lev. 19:18 with a view of its fulfilment in life in the light of the kingdom of God.'

17. For the interpretation of the double commandment of love in light of the kingdom theology, see Wilkens (2002:252ff.).
God loves the world and he comes back to her to establish his loving and just reign. He created the world and he knows best what is good for her and what an autonomous world misses by going her own ways. Missio Dei is concerned to establish God's kingdom in the world. Consequently, Jesus begins his public activity with the words: 'Repent, for the kingdom of heaven has come near' (Mt 4:17). The reign of God and his kingdom are in fact 'the central themes of Jesus' (Wilkens 2002:131). He preached the kingdom and proclaimed the presence of the kingdom in his own person (Goppelt 1978:104ff.; Kümmel 1976:30-35; Wilkens 2002:131ff.). He healed the sick, liberated demoniacs and set signs of the approaching kingdom.

No other text describes his ministry better than Lucas 4:18-19. Jesus is in a synagogue in Nazareth. He reads Isaiah 61:1-2, a text which the Jewish tradition has always interpreted in light of the messiah to come and introduce God's kingdom among his people. Jesus reads the text and "then he rolled up the scroll, gave it back to the attendant and sat down. The eyes of everyone in the synagogue were fastened on him. He began by saying to them, "Today this scripture is fulfilled in your hearing" (Luc 4:20-21). In him, Jesus, this prophecy has been fulfilled. The Year of Jubilee has come, God's kingdom is in the process to become a reality. And this kingdom will cover all human existence. The political dimension of what is following is at hand. God's reign is real; his kingdom encompasses all spheres of life. Nothing is excluded. His kingdom is never only spiritual; it is also material, social and cultural. Jesus includes all those aspects of life when he introduces the kingdom in his famous parables (Wilkens 2002:163-183; see also Capon 1985). God's all-encompassing reign on Earth - this is what the disciples of Jesus are asked to pray for when Jesus teaches them: 'This, then, is how you should pray: "Our Father in heaven, hallowed be your name, your kingdom come, your will be done, on earth as it is in heaven"' (Mt 6:9-10).

God aims to transform the world in such a way that it is what he wants it to be. And the question is: how would a world ruled by God look like? Jesus did not talk much about the actual state in which the world under the reign of God is to be imagined. The only qualification he gives is that the world in the kingdom of God will be NEW. ${ }^{18}$ He refers to the prophets, who also imagined the eschatological world as a new world. For instance, Isaiah who hears God saying: 'See, I am doing a new thing! Now it springs up; do you not perceive it? I am making a way in the wilderness and streams in the wasteland' (Is 43:19). And Jesus refers to Isaiah again and again. His theology of God's kingdom reflects his prophecy, for instance, in his teaching about the eschatological fest in Mt 8:11; Mark 14:25 par; Luc 22:29f.; a.o.) with the fest God has prepared for the nations at the end of times as Isaiah sees it (Is 25:6). Jesus obviously refers to the teachings of the prophet on the kingdom. ${ }^{19}$ And his listeners understood him well. In their 18.See, for instance, Mark (2:24/par).

19.For more about the correlation between the teachings of Jesus and the prophet Isaiah, see Wilkens (2002:134ff.). 
imagination, they have seen a reconciled with God world as described in Isaiah 65. Here God promises:

See, I will create new heavens and a new earth. The former things will not be remembered, nor will they come to mind. But be glad and rejoice forever in what I will create, for I will create Jerusalem to be a delight and its people a joy. I will rejoice over Jerusalem and take delight in my people; the sound of weeping and of crying will be heard in it no more. 'Never again will there be in it an infant who lives but a few days, or an old man who does not live out his years; the one who dies at a hundred will be thought a mere child; the one who fails to reach a hundred will be considered accursed. They will build houses and dwell in them; they will plant vineyards and eat their fruit. No longer will they build houses and others live in them, or plant and others eat. For as the days of a tree, so will be the days of my people; my chosen ones will long enjoy the work of their hands. They will not labour in vain, nor will they bear children doomed to misfortune; for they will be a people blessed by the Lord, they and their descendants with them. Before they call I will answer; while they are still speaking I will hear. The wolf and the lamb will feed together, and the lion will eat straw like the ox, and dust will be the serpent's food. They will neither harm nor destroy on all my holy mountain", says the Lord (pp. 17-25).

God's new world as the prophet hears it is a socially just world. Whoever lives in this world will no longer live under oppression, will earn his living freely, will have a house for his family and health to his body. It is a world in which blessing rules the day. God's blessing! And even the animals will experience harmony and peace. It is a world in which God is present! This world is God's missionary goal - a world under his rule - his kingdom! And the church is his chosen people - a people, a nation of the kingdom. No, the church is not God's kingdom, but she belongs to the kingdom as Ladd rightly claims (Ladd 1974:111). Consequently the disciples of Jesus preached the gospel of the kingdom and not of the church (Ac 8:12, 1:8, 20:25, 28:23.31). It was the kingdom they preached in the world (Mt 24:14).

We summarise that God, the creator of the world, loves his creation and seeks for righteous ways to bring the world back under his divine and loving rule. It is the kingdom of God that marks his missionary commission, the kingdom he seeks to establish on earth as it is in heaven.

\section{Missio Christi - God's way of transformation}

Jesus was 'God's best missionary' (Escobar 2006:97). Never ever has a human being been as close to God's heart as Jesus, never ever as obedient to God's call. He totally identified with the will of God for his life and therefore God gave him a name above all names (Phlp 2:11). In fact, his name is the only name under the sun by which humans will be saved (Ac 4:12). He is the only appropriate way to God (Jn 14:6). Wherever the mission of God is attempted, Jesus will be the model to consider. To his own disciples, the resurrected Christ said: 'As the father has sent me. I am sending you' (Jn 20:21). The church is sent, as Jesus was sent. There is no extra sending for the church, no extra model of mission. She is his Body in the World (Eph 1:23). Nothing will be as important for the church on Earth than the imitatio Christi, the obedient following in the footsteps of Jesus.

So, what was the mission of Jesus? How did he accomplish the task? Let's consider the following (Reimer 2017:39-41).

\section{The mission of Jesus began with incarnation}

In John 1:1-6; 1:9-14, we read:

In the beginning was the Word, and the Word was with God, and the Word was God. He was with God in the beginning. Through him all things were made; without him nothing was made that has been made. In him was life, and that life was the light of all mankind. The light shines in the darkness, and the darkness has not overcome it.... The true light that gives light to everyone was coming into the world. He was in the world, and though the world was made through him, the world did not recognize him. He came to that which was his own, but his own did not receive him. Yet to all who did receive him, to those who believed in his name, he gave the right to become children of God - children born not of natural descent, nor of human decision or a husband's will, but born of God. The Word became flesh and made his dwelling among us. We have seen his glory, the glory of the one and only Son, who came from the Father, full of grace and truth.

Jesus - God himself becomes flesh in order to reveal to us the glory of God. Incarnation marks the point of total dedication, the kenosis [Greek], the emptying of himself of Jesus (Phlp 2:7). Here the authors of the New Testament see the 'focal point of missio dei' (Murray 2001:42). God's word for salvation, his final and ultimate concept to save the world is Jesus (Heb 1:1). And Jesus was first of all a man like us, a Jew from the Jews, in everything tempted like us, but without sin (Heb 4:15). Born in Bethlehem, grown up in Nazareth with his parents Maria and Josef, he was, in every regard, a member of the social and cultural community of his nation.

\section{Incarnation of Jesus was an act of dedication to service the people of Israel}

The gospels are full of stories showing the reader how humanic his life and ministry was. Just consider his first miracle in Kana. At a wedding celebration he turned water into wine because the celebrating family ran out of wine (Jn 2:1ff.). Jesus brought joy into the fest. He healed the sick, freed spirit-possessed people from demonic oppression, fed the hungry and cared for the wounded. His words were followed by deeds (Ac 10:36-38; Luc 9:11). He spoke about the kingdom and demonstrated the power of God's kingdom in what he did. 'Not the healthy need a doctor, the sick are', Jesus said, and he added: 'The son of man has not come in order to be served, but to serve' (Mt 20:28). He was God's servant (Luc 22:27). God meets us humans in the man Jesus of Nazareth. Whoever will in future search for God will find him in the son of man, Jesus (Jn1:18, 14:9)! Mission, as Jesus saw it, is a matter of servanthood. He served, and he advised his disciples to do the same (Jn 13:13f.). 


\section{Jesus served to transform}

In Jesus God reconciled the world with himself (2 Cor 5:18-19). Salvation is what he brought to the world (Ac 4:12). With him God's promise of Jubilee became reality (Is 61:1-2; Luc 4:18). The American theologian John Howard Yoder (1927-1997) strongly believed that the year Jesus was referring to the Jubilee would have actually been one of the 50th years in the history of Israel. Israel never kept the law of God in this regard. Over the centuries Jubilee became a synonym for the messianic eschatological kingdom. Now Jesus was connecting his ministry to the Jubilee claiming to be the promised messiah. In his great book The Politics of Jesus, Yoder (1981) points to the social and political dimensions of Jesus ministry closely related to the Jubilee narrative. According to Yoder, Jesus introduces with his ministry a movement of social change (1981:25-26). He even claims the teachings of Jesus are normative for a Christian social ethics (1981:21) and must be understood against the Jubilee-law in the Old Testament (1981:59-69).

\section{Transformation introduced by Jesus aims towards the kingdom of God}

Jesus proclaimed the gospel of the kingdom of God (Luc 4:43; Mt 4:17). His ministry, as we have seen above, was kingdom centred.

\section{Jesus creates a new people of the kingdom - The church}

To Peter, who realises that Jesus is the messiah of God, Jesus says: 'You are Simon Peter and on this rock, I will build my church and the fortress of hell will not prevail against her' (Mt 16:18). His people are a new holy nation, a royal priesthood (1 Pt 2:9-10).

We summarise that Missio Christi is God's method and model to establish his kingdom. It includes incarnational service and proclamation with the aim to transform all life under the reign of God.

\section{Missio Spiritus - God's praxis of transformation}

The mission of the church started on Pentecost. With the coming of the Holy Spirit in Jerusalem (Ac 2:1ff.), both the church and its mission were born. It is the Spirit of God heads up the mission and builds the church in the world. The scripture leaves here no question (Ewert 1983:200f.). The church is founded, and the church is sustained by the Holy Spirit (1983:201). It is through the Spirit that men believe in Jesus (1 Cor 12:3), through the Spirit they are formed into one body of Christ, the Church (1 Cor 12:13), through the Spirit they receive gifts and ministries (1 Cor 12:4-5). The church is called a fellowship of the Spirit, a house of God (1 Cor 3:16), a 'spiritual house' (1 Pt 2:5), a place where God lives (1 Cor 6:19).

The mission of God in the world is directly related to what the Spirit does. In fact, he is the Lord of mission (2 Cor 3:17). What does this mean in practical terms?

\section{The Holy Spirit is the creator fidae, the founder of faith}

When Jesus promised his disciples to send to them the spirit, he stressed the fact that it would be him, who comes to convince the world of sin, righteousness and justice (Jn 16:8), him who would lead the disciples in all truth reminding them of all Jesus taught them (Jn 14:26, 16:13). And he commanded them not leave Jerusalem until the Holy Spirit would fall on them and make them witnesses unto the end of the world (Ac 1:8). For Jesus it is clear - a relationship to him is only possible through the Spirit. Apostle Paul underlines this in 1 Corinthians 12:3 by claiming that no one will be able to call Jesus Lord except through the Holy Spirit. The Spirit of God is the 'point of departure of faith' (Fee 2005:129). Whoever longs for the fellowship with God will have to be born again (Jn 3:5), an experience of being baptised in the Holy (Tt 3:5). Only those people who are sealed with the Spirit (Eph 1:13f.), who 'possess' the Spirit (Rm 8:9), are able to live in power and glory of God the father and do what Jesus has commanded them to do (Jn 16,7). It is, as Clowney rightly says, 'the Spirit who leads to Christ' (Clowney 1995:51). Without the Holy Spirit there can be no relationship to Jesus the Christ. And without it there will be no relationship to God the father. Only those who are led by the Spirit of God are Children of God. He gives clarity to our spirit that we are children of God (Rm 8:14-16).

\section{The Holy Spirit is the creator ecclesiae, the founder of the church}

As we have seen, the church was born on the day of Pentecost. Already the prophets of the Old Testament related the renewal of God's people to the coming of the Holy Spirit (see, for instance, Is 32:15, 44:3; Ez1:19, 36:26f., 37:14; J1 3:1f.). Peter consequently declares to the Jews gathered from all the nations in Jerusalem on the day of Pentecost that the outpouring of the Spirit is a fulfilment of prophecy. And he urges them to repent (Ac 2:37f.). And 5000 do repent and are being baptised in the name of Jesus. They are the first to join the church of Christ. The church is born in the presence of the Holy Spirit (Lohfink 1982:96). And it is born from all the nations gathered in Jerusalem. The nation of God becomes a universal reality. The disciples of Jesus coming from the Jewish nation are now being called to go to all nations of the world (Ac 1, 8). Through Pentecost the disciples of Jesus receive their global messianic identity (Roloff 1993:63-64).

He, the Holy Spirit, is the creator of the new collective, the new social institute called 'Body of Christ', building the actual structure of God's people on Earth (1 Cor 12:13). This body is continuing what Jesus started in the world to the praise of his glory (Eph 1:3ff.). This body is spiritual, does not belong to the world around us, but it is in the world and as such for the world (Jn 17:17ff.). The church is spiritual, but it is also a social structure. It is not from the world, but is still in the world and only here is its divine calling. The spirit of God builds the church as a universal 
reality. Everybody in the world is welcomed, no one is excluded. He provides his gifts to every person coming to faith in Christ (1 Cor 12,4-6), opening this way a place of service and dignity in the kingdom.

\section{The Holy Spirit is dominus missii, the Lord of mission}

Where the Spirit of God is involved, there is witness in the world and powerful proclamation of the gospel (Hahn 2002:280). Jesus indicates this to his disciples, pointing to the fact that the experience of the spirit will lead to witnessing in Jerusalem, Judea ... and to end of the world (Ac 1:8). The church begins as a witnessing community sent to all the nations of the world. And he, Jesus himself, grants his disciples his spirit before he sends them to the mission the father has sent him (Jn 20:21). Wherever his disciples will join his mission, they will do so in the 'Spirit and Power' (1 Cor 2:4). Christians are servants of the new covenant 'not the covenant of the letter but of the Spirit' (2 Cor 3:6). And he, the Holy Spirit, is the Lord of God mission, implementing what the father wants in the way Jesus has suggested (2 Cor 3:17).

We summarise that the mission of the Spirit of God is to create faith in people, join them into a missionary people for realisation of God's kingdom in the world.

\section{The mission of the triune God}

God is a missionary God. And he revealed himself to us as Father, Son and the Holy Spirit. His Self-revelation is interrelated. As his nature is basically a reciprocal interiority, his mission is equally interconnected - what the father wants, the Son puts into a system and the Spirit into praxis. The cycle of the missio Dei consists of God who lays the foundation, Jesus who determines the way of salvation, the methodology and the Holy Spirit who leads the praxis.

This divine cycle is functional because unity and absolute love carry the movement. The mission Dei is only possible because of the complete unity of the tree in one. Foundation,

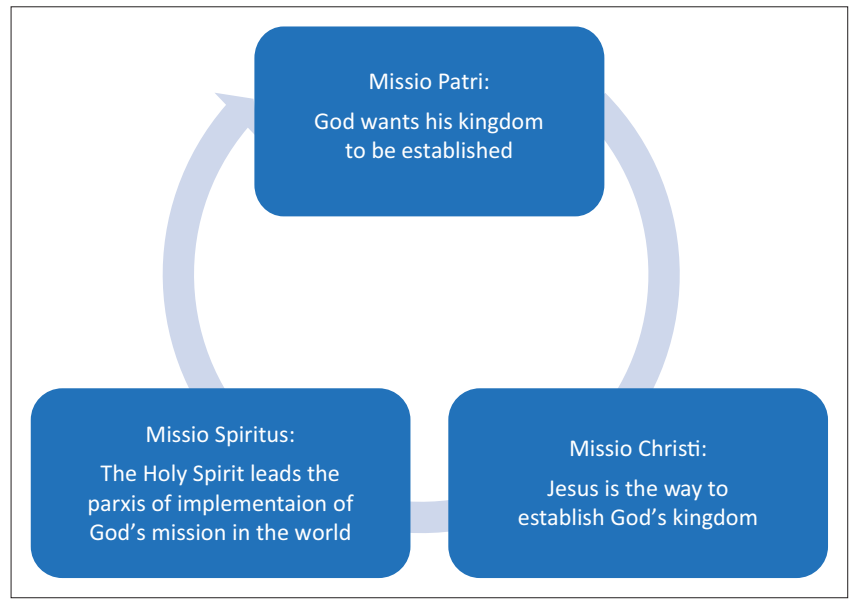

FIGURE 2: The divine perichoresis of mission. method and praxis are completely and definitely interlinked (Reimer 2013:160, 2017:44). Loving relationship and missional existence go hand in hand. This is where the missionary church of today has to be rerooted in order to become a missional factor in community again (see Figure 2).

\section{Acknowledgement Competing interest}

The author declares that no competing interest exists.

\section{Author contributions}

I declare that I am the sole author of this research article.

\section{Funding}

This research received no specific grant from any funding agency in the public, commercial, or not-for-profit sectors.

\section{Data availability statement}

Data sharing is not applicable to this article as no new data were created or analysed in this study.

\section{Disclaimer}

The views and opinions expressed in this article are those of the authors and do not necessarily reflect the official policy or position of any affiliated agency of the authors.

\section{Ethical consideration}

This article followed all ethical standards for carrying out research without direct contact with human or animal subjects.

\section{References}

Bosch, D.J., 2011, Transforming mission. Paradigm shifts in theology of mission, Orbis, Maryknoll, NY.

Capon, R.F. \& Clucas, L., 1985, 'The triumph of mysticism in Byzantium in the fourteenth century', in S. Vryonis Jr (ed.), Byzantine studies in honor of Milton V. Anastos, Byzantina kai Metabyzantina, vol. 4, UNdena Publication, Malibu, CA, Digital version, viewed n.d., from http://www.myriobiblos.gr/texts/english/ clucas_mysticism5.html.

Clowney, E.P., 1995, The church, IVP, Leicester

Demina, N.A., 1972, Andrei Rublev i chudozhniki yego kruga, Nauka, Moskva.

Dunaev, M., Troica prepodobnogo Andreya Rubleva, viewed 01 February 2019, from http://www.infonet.ee/ ettnat/Troitsa.html.

Escobar, S., 2006, La Palabra: Vida de la Iglesia, Editorial Mundo Hispano, Atlanta.

Ewert, D., 1983, The Holy Spirit in the New Testament, Herald Press, Scottdale.

Fee, G., 2005, Der Geist Gottes und die Gemeinde, Leuchter, Erzhausen.

Freitag, W., 1950, 'Vom Sinn der Weltmission', Evangelische Missions-Zeitschrift 1, 1-8.

Gladis, G., 1999, Leading the team-based Church, Jossey-Bass, San Francisco, CA.

Golubinski, E.E., 1892, Prepodobnyi Sergi Radonezhski I sodannaia im Troickaia Lavra, Moskovski Universitet, Moskva.

Goppelt, L., 1978, Theologie des Neuen Testmants, Vandenhoeck \& Ruprecht, Göttingen.

Hahn, F., 2002, Theologie des Neuen Testaments, vol. 2, Mohr-Siebeck, Tübingen.

Ilyin, M.A., 1976, Isskustvo moskovskoi Rusi Feofana Greka und Andreya Rubleva, Isskustvo, Moskva.

Kümmel, W.G., 1976, Theologie des Neuen Testaments nach seinen Hauptzeugen Jesus, Paulus, Johannes, GNT vol. 3, Vandehoeck \& Ruprecht, Göttingen. 
Ladd, G.E., 1974, The Gospel of the Kingdom. Scriptural studies in the kingdom of God, Eerdmans, Grand Rapids, MI.

Lazarev, V.N., 1983, Russkaya ikonopis, vol. 1, Isskustvo, Moskva.

Lohfink, G., 1982, Wie hat Jesus Gemeinde gewollt, Herder, Freiburg.

Lossky, V., 1947, 'V.W., Uspensky L', The meaning of icons, London.

Lossky, V., 1997a, The Mystical theology of the Eastern Church, SVS Press, New York.

Marshall, H.I., 2004, New Testament theology, IVP, Downers Grove.

Meyendorff, J., 1964, A study of Gregory Palamas, Faith Press, London.

Moltmann, J., 1991, Geschichte des dreieinigen Gottes. Beiträge zur trinitarischen Theologie heute, Kaiser, München.

Müller, W., 1990, Dionysios Areopagites und sein Wirken bis heute, Pforte Verlag, Dornach.

Murray, S., 2001, Church planting, Paternoster, Carliste.

Nikiforov, N., 2001, 'Ikona svyatoi troicy prepodobnogo Andreya Rubleva', Pravoslavnaya Zhisn' 51(5), 616, viewed from http://pravoslavie.domainbg.com/ rus/07/troica/nikoforov_rublev.html.

Polunin, V.A., 1974, Mirovozreniye Andreya Rubleva, Moscow University Press, Moskva.

Popova, O.S., 1980, Isskustvo Novgoroda i Moskvy vervoj poloviny XIV veka: Yego svyazi s Vizantiyei, Isskustvo, Moskva.

Ratner, L.N., n.d., Prostranstvo ikony Andreya Rubleva kak dialog, viewed 01 February 2019, from http://209.85.135.104/search?q=cache.

Raushenbach, B.V., n.d., '... Predsoya Svetei Troice (Peredacha troichnogo dogmata $b$ ikonach),' viewed 01 January 2019, from http://nesusvet.narod.ru/ico/books/ raushen/predstoya.htm.

Reimer, J., 1994, Missionsarbeit des frühen russischen Mönchtums. Unpublished DTh Thesis, Unisa, Pretoria.

Reimer, J., 1996, Missionerskaya deyadel'nost drevnerusskogo monashestva, Logos, Lage.
Reimer, J., 2008, 'The spirituality of Andrei Rublev's icon of the Holy Trinity', Acto Theologica Suplementum 11, 166-180.

Reimer, J., 2013, Die Welt umarmen. Theologie des gesellschaftsrelevanten Gemeindebaus, Francke Verlag, Marburg.

Reimer, J., 2017, Missio Politica. Corelation between mission and politics, Langham, Carliste.

Roloff, J., 1993, Die Kirche des Neuen Testaments, NTD Ergänzungsbände, vol. 10, Vandenhoeck \& Ruprecht, Göttingen.

Sergeyev, V.N., 1981, Rublev, Molodaya Gvardiya, Moskva.

Tamcke, M., 1994, 'Rubljow, Andrej', in BBKL, pp. 908-911, viewed 01 February 2019, from http://www.bautz.de/bbkl/r/rubljow_a.shtml.

Ulyanov, O.G., 2005, Nasha nacionalnaya idea - eto rublevskaya troica. Tri daty Andreya Rubleva, viewed 01 February 2019, from http://www.icon-art.info/ book_contents.php?book_id=14.

Uspenski, L.A., 1989, Bogosloviye ikony pravoslavnoi cerkvi, West-European Administration of the Moscow Patriarchat, Paris.

Volf, M., 1998, After our likeness. The church in the image of the Trinity, Eerdmans, Grand Rapids, MI.

Vzdornov, G., 1981, Trinity by Andrei Rublev. An anthology, Iskusstvo, Moscow.

Wikiart, n.d., Rublev: The icon of the Holy Trinity, viewed n.d., from https://www.

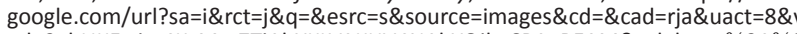
ed=2ahUKEwim4KyMm7TiAhXKLVAKHV4NAhYQjhx6BAgBEAM\&url=https $\% 3 A \% 2$ F\%2Fwww.wikiart.org\%2Fde\%2Fandrei-rubljow\%2Fdreifaltigkeitsikone-1410\& psig=AOvVaw3gDdsunm5NuQXqfuURZgg-\&ust=1558788844354322.

Wilkens, U., 2002, Theologie des Neuen Testaments Geschichte der urchristlichen Theologie, Teilband 1: Geschichte des Wirkens Jesu in Galiläa, Neukirchner Verlag, Neukirchen-Vluyn.

Wright, C., 2006, The mission of God: Unlocking the Bible's grand narrative, IVP Academic, Downers Grove.

Wright, T., 1992, Bringing the Church to the World, Bethany House, Minneapolis, MN. 